\title{
"A Question of Integrity": Academic Values Torn Between Organizational Affiliation, National Competitiveness and the Global Academic Community
}

\author{
Michael Hölscher
}

Values of higher education, as supported by the IAU, ${ }^{1}$ are grounded in the beliefsystems and behaviour of the individual researchers/teachers and the academic community more generally. Although these values are influenced from the outside by educational policies and economic considerations, and although they also encompass societal views on science (e.g. trust in science), it is academia itself that has to uphold, and sometimes defend, the inner principles of higher education.

Individual academic freedom and values, however, are under pressure from different quarters. On the meso-level, higher education institutions, due to increased competition and accountability, have moved over the last 70 years from being "organized anarchies" to organizations that are fully administered, demanding loyalty from their members. On the macro level, especially in the context of the knowledge society or knowledge economy, higher education (HE) is now regarded as a significant part of a nation's innovative competitiveness, with important impacts on internationalization strategies, for example. In this essay, I would like to develop some ideas on the interplay of these three levels, and how academic values can be maintained in this field of tension.

Although even older than the IAU, Merton's ethos of science from 1942 is still a good starting point for looking at academic values ${ }^{2}$ :

- Communality (originally called “communism”): common ownership of scientific results

\footnotetext{
${ }^{1}$ Please see the official webpage of IAU: https://www.iau-aiu.net/Vision-Mission.

${ }^{2}$ Describing the principles in just one sentence does not give justice to Merton's ideas, so I recommend reading the original text in "A Note on Science and Technology in a Democratic Order".
}

M. Hölscher $(\varangle)$

German University of Administrative Sciences Speyer, Speyer, Germany

e-mail: hoelscher@uni-speyer.de 
- Universalism: evaluation of scientific truth has to follow impersonal criteria, independent of personal attributes of the researcher

- Disinterestedness: science should be pursued for the common good, not for personal gain

- Organized scepticism: scientific findings need to be thoroughly scrutinized.

Merton does not claim that these principles are always in force or adopted, and he already mentions that competition could put pressure on them. Nevertheless, these four principles can work as a guiding line for our behaviour as academics and help guarantee the functioning of science along its own logic. The combination of his global ethos of the scientific community and individual academic freedom is the basis for unbiased and joint truth-seeking as the main spirit of science.

Developments, especially during the last two or three decades, undermine this ethos as well as academic freedom. There are many direct pressures from populist and authoritarian governments on higher education institutions, and we see an overall decrease in funding in many countries (see OECD's "Education at a Glance" for figures). I would like, however, to concentrate here on two related trends connected to the growing importance of higher education for society and the economy in the context of a knowledge society. These trends, at first sight, are often seen as beneficial, but they increase non-scientific claims on academia with important repercussions for academic values.

On the macro-level, higher education is increasingly seen as (one of) the most important input(s) for a nation's economic competitiveness. Tertiary education and innovation from research are the drivers of growth in the knowledge economies of industrialized countries. Governments often deliberately force their HE institutions to contribute to this competitiveness, and as the state is still the main funding body of $\mathrm{HE}$ in most world regions, they also have the means of doing so. International organizations such as the World Bank act in the same vain, as they see HE often from an economic perspective and focus on its contribution to development. While pushing universities to excel in teaching and research would not be a problem per se (on the contrary!), many current initiatives focus on benefits for their own nations only. For example, many countries have developed so-called excellence initiatives during the last few years (e.g. Germany's "Excellence Initiative/Strategy", China's "Projects 211 and 985" or Russia's "Project 5-100"), virtually always with the aim of improving their nations' competitive position in the international market.

This trend undermines the scientific ethos in at least two ways. First, on the international level, it contributes to a predominantly strategic approach to international scientific collaboration. As countries strive to improve their universities' positions in international rankings in conjunction with their business competitiveness, principles such as communality (sharing research results instead of patenting them or hiding them behind pay-walls) or disinterestedness (the common good is often much broader than regional or national interests) are counterproductive for these goals.

Second, instead of using resources to improve the scientific system overall, such initiatives often make universities within a country compete with each other, leading to a stratified system of some winners and many losers (often following the Matthew 
effect: "For whosoever hath, to him shall be given, and he shall have more abundance: but whosoever hath not, from him shall be taken away even that he hath."). Again, competition as such may not be bad, as long as it works along scientific rationales and is characterized, first and foremost, by a competition for prestige as the currency of science. However, in reality, these initiatives redistribute financial resources introducing non-scientific incentives for organizations and individual researchers.

This leads us to the second, the meso-level of the organization. Universities have long been described as "specific organizations" (Musselin 2007) or even "organized anarchies" (Cohen et al. 1972). One of the reasons is that in science as a "profession" academics accept only their peers' judgement as a legitimate evaluation of the quality of their work. Therefore, academics' identities are often shaped far more by their scientific discipline than by their university (for different reasons this is probably much more so in Germany than, for example, in the US, but probably holds true for many regions of the world). As a result, universities are a rather loosely coupled system (Weick) of faculties with a relatively weak centre.

In the wake of the utilization of higher education by nation-states as described above, universities as organizations are being held responsible to "deliver". New Public Management reforms have increased organizational autonomy and competition between universities, raising the need for central steering and strategic decisions at the leadership level of the whole organization. International university-rankings (not of individual researchers!) additionally contribute to the focus on higher education organizations. Universities, therefore, need to become "entrepreneurial" (Clark 1998) actors in their own right. Again, there is nothing negative about usefully pooling resources to increase research capacities and effectiveness, or in improving central administrative tasks. However, too often university organizations-following external incentives such as third-party funding or increasing student figures to increase income, etc. - alter their strategies not necessarily for the good of science or society, but for the good of the specific organization. In Germany, for example, as in many other countries, universities are allowed to withhold research findings if they see a chance of gaining income from patents stemming from that research. Such organizations are tempted to reduce academic freedom and communality using researchers and teachers to reach non-science-inherent goals such as growth or legitimacy (e.g. as proposed by neo-institutionalist theory).

To summarize my argument here: The in principal welcome growing importance of higher education for society and the economy may, in fact, contribute to the corruption of academic values by (a) rewarding social and economic benefits for nation-states or the organization more than contributions to global science and (b) increase the relevance of non-scientific incentives, mainly economic ones, within academia. One reason for this is the at times excessive use of science to serve a wider political agenda of enhanced national and international competitiveness, another the resulting increased focus on HEIs as actors in toto instead of the work of individual researchers/teacher or research/teaching groups. With regard to accountability and impact, governments tend to deal with organizations rather than individuals. Both, nation-states and HEIs, follow other rationales than science. While academic values and the scientific ethos, as outlined above, foster universalism, communality and 
openness for the common good, states as well as HEIs have to delimit knowledgeexchange to be able to exploit added value of science to their own advantage.

It is, of course, rational for states, organizations and individuals to strive for their own advantage. The task of academic values and the ethos of science, supported by the high intrinsic motivation of academics, is to transform this self-interest into scientific progress and benefits for the common good. To foster academic values in this endeavour, it is important to recognize and confer status especially to those academics who appreciate this scientific ethos and who transform their intrinsic interests into hard scientific work. It is our duty as peers to make sure that we do not base our recognition mainly on the number of publications and impact factors, or on the acquisition of third-party funding. Instead, we should appreciate academics that truly contribute to global knowledge and formative education (in German you could add "Erkenntnis" and "Bildung" in a broader sense) as the main goals of higher education.

A good example is the sequencing of the human genome. While Craig Venter, researcher-turned-entrepreneur with his company Celera Genomics and extensive financial backing, sought to decipher the human genome purely for the end of acquiring a patent, researchers from all over the world pooled their resources in the "Human Genome Project" to make the results freely available. Today, during the Covid-19 pandemic, the international scientific community is working together in all parts of the globe in order to make quick progress into finding a treatment for the virus and a vaccine which will benefit everyone ("the common good"), instead of competing for quick wins to increase a specific university's/company's/nation's income. Additionally, we can also identify how important an "organized scepticism"-dimension is, as the publication of premature research findings in the race for the first place may not only discredit the actual researcher but science and higher education overall.

In times of big science and global grand societal challenges on the one hand, and increasing pressure from organizational and national agendas on the other, it is of utmost importance that we defend our academic integrity against mainly economically-driven interests, and promote science's ability to contribute to truth and human wellbeing. Therefore, it is increasingly important to foster international cooperation in the spirit of the above-outlined ethos of science instead of trying to maximize national benefits. In this, organizations such as UNESCO and the IAU have an important role to play: to help overcome national and organizational selfishness.

\section{References}

Clark, B. R. (1998). Creating entrepreneurial universities. Organisational pathways of transformation. Oxford/New York: Pergamon Press.

Cohen, M. D., March, J. G., \& Olsen, J. P. (1972). A Garbage Can Model of Organizational Choice. Administrative Science Quarterly 17(??), 1-25.

Merton, R. K. (1973) [1942]. The Normative Structure of Science. In R.K. Merton (Ed.), The Sociology of Science: Theoretical and Empirical Investigations (pp. 267-278). Chicago: University of Chicago Press. 
Musselin, C. (2007). Are Universities specific organisations? In G. Krücken, A. Kosmützky \& M. Torka (Eds.), Towards a Multiversity? Universities between Global Trends and national Traditions (pp. 63-84). Bielefeld: Transcript.

Michael Hölscher is Professor of Higher Education and Research Management at University of Speyer. His fields of interest are international comparisons of higher education systems; cultural sociology; innovation and creativity.

Open Access This chapter is licensed under the terms of the Creative Commons Attribution 4.0 International License (http://creativecommons.org/licenses/by/4.0/), which permits use, sharing, adaptation, distribution and reproduction in any medium or format, as long as you give appropriate credit to the original author(s) and the source, provide a link to the Creative Commons license and indicate if changes were made.

The images or other third party material in this chapter are included in the chapter's Creative Commons license, unless indicated otherwise in a credit line to the material. If material is not included in the chapter's Creative Commons license and your intended use is not permitted by statutory regulation or exceeds the permitted use, you will need to obtain permission directly from the copyright holder. 